Moscow Institute of Architecture (State Academy) Vice-president of the Russian Academy of Arts President of the Russian State Academy of Architecture and Building Sciences e-mail: shvidkovsky@gmail.com Moscow, Russia

ORCID 0000-0001-6799-2305 ResearcherID X-6256-2019

Nikolay A. Korotaev Docent, Assistance Manager for Church Architecture Departmen Moscow Institute of Architecture (State Academy) e-mail: nikolyasarkozi@inbox.ru Moscow, Russia

\section{THE MEANING OF SHATER FORM IN THE ARCHITECTURE OF RUSSIAN RENAISSANCE OF THE 16TH CENTURY*}

Summary: The article is intended to clarify the original signification of a tent-shaped roof in church architecture in order to help Russian architects of the $21^{\text {st }}$ century to use it meaningfully and in ac cordance with centuries-old tradition.

The article deals with the problem of the genesis of the tent-shaped roof of the church and its primitive meaning in a wide cultural and symbolic context. Within the frame of a longstanding scientific discussion that lasted a century and a half different opinions had been expressed: the origin of the tent-shaped roof was linked with the traditions of Russian timber constructions as well as with the influences of Armenian, Georgian and even Indian architectural traditions. The article discusses the historical and culturalogical context of the creation of the first known masonry tent-shaped roof in the

Church of the Ascension in Kolomenskoye built ac cording to the commission of the Grand Duke Vasily III. The date of completion of the church is documented - that happened in 1532. The authorship of the project was discussed for a long time. Now it is considered to be definitely proved that the author was an Italian architect Petrok Maly (Pietro Annibale di Piza). The authors show the link of the meaning of the church in Kolomenskoye with the conceptions of Moscow as the New Constantinople and the Third Rome. We show the similarity of forms of the muscovite church with the description of the ciborium of the church of Saint Sophia in Constantinople in the text of Saint Germanus of Constantinople, known in the $16^{\text {th }}$ century Russia.

Keywords: Russian architecture, Renaissance, form meaning, origin

The research was carried out with the financial support of the Russian Foundation for Basic Research within the framework of the scientific project
tural Education».
The question of the emergence of tented roofs of Russian churches has long been considered in detail in historiography and is fully reflected in the last book by A.Batalov and L.Belyaev, dedicated to the Church of the Ascension in Kolomenskoye. In this article, we are trying to show the original meaning of a tented roof as a ciborium, based on the need for a meaningful, tradition-based interpretation of this art form by Russian church architects in the $21^{\text {st }}$ century.

In 1492, the Orthodox world was expecting the end of the world. According to the chronology, which started from the supposed date of the creation of the world, the seventh millennium ended. When the year 7000 passed safely, the expectation of a universal catastrophe was replaced by the desire to determine a long historical perspective and see the features of the future.

Metropolitan Zosima spoke in Moscow promoting a new calendar of the main church holidays - paschalion. In his narration of the "na os'muyu tysyachu let... v ney zhe chasy... prishestviya Khristova..." [after eighth thousand years... at the hour... of the coming of Christ] paschalion, he expressed thoughts developing the ideas of St. Metropolitan Jonah about the Russian Church as the focus of "prezhnego grecheskogo bogoustanovlennogo blagochestiya" [the former Greek godly piety]. And now, it was already a question of transferring the ideas of the empire of the righteous Christian kingdom to Russian soil. "I nyne zhe... proslavi Bog... blagovernogo i khristolyubivogo velikogo knyazya Ivana Vasil'yevicha, gosudarya i samoderzhtsa vseya Rusi, novogo tsarya Konstantina novomu gradu Konstantinu Moskve" ${ }^{11}$ [and now ... Lord, glorify ... the noble and Christ-loving Grand Duke Ivan Vasilyevich (Ivan III - author), the sovereign and autocrat of all Russia, the new Tsar Constantine to the new city Constantine of Moscow]. In addition earlier in the chronicles, Russian sovereigns were often compared with Emperor Constantine. However, a significant innovation appeared in the work of Metropolitan Zosima. For him, Moscow was not just "new Constantinople", not only the center of the Orthodox world but it was its last capital, which should exist until the Second Coming of Christ.

Such thoughts, which arose at the end of the reign of Ivan III, became the basis of the political ideas that 1. Russian Historical Library. Vol.6, part 1. St.Petersburg, 1908 No. 118, columns 795-796; Zosima, Metropolitan of All Russia. The sictionary of scribes and bookishness of Ancient Russia. 1988, pp. 305-307. prevailed in Moscow under Vasily III and determined the features of the use of the architectural ideas of the Russian Renaissance. Russian thought was getting closer and closer to perceiving Moscow not as new Constantinople but as «Third Rome», the last empire that «will endure until the end of time».

A fierce discussion on this topic, which influenced the development of Russian architecture, unfolded in Moscow during the reign of Vasily III. Thus, Nicholas Bulev, who came from Germany, an expert in medicine and astrology, "the most thorough in all sciences" 32 , appeared in Moscow in 1508. Soon afte becoming a court doctor, he quickly became one of the closest companions of the Grand Duke Vasily III. The German scientist was a supporter of the "First Rome" - a combination of the ideas of the empire and the idea of the supremacy of the papal throne in the Christian world. In addition, he believed in the prediction of the end of the world in 1524, which was widespread in Germany at that time.

This contradicted the dream of the last Byzantines and their Moscow supporters to create the last Orthodox kingdom in Russia. They all opposed Nicholas Bulev. Byzantine humanist Maximus the Greek ${ }^{3}$ played a significant role in these disputes. Having emigrated to Italy, he collaborated with John Laskaris and Giovanni Francesco Pico della Mirandola there. Afterwards, disillusioned with Catholicism, he moved to Athos, and in 1516, hav ing moved to Moscow, entered into a dispute with the German physician, trying to prove the superiority of the Byzantine Orthodox tradition. On the eve of the end of the world predicted by the German astrologers to happen in 1523 or 1524 , he was supported by monk Philotheus in his famous epistle, To the Astrologers. The treatise of the elder from the Elizariev Monastery near Pskov ${ }^{4}$ was closely connected with Moscow court life; thus, its appearance was probably instigated by those

2. Miller D. The Lubeckers Bartholomaus Ghotan and Nicolas Bulow in Novgorod and Moscow and the Problem of Early Western Influences on Rusian Culture. Viator, 1978, n. 9, pp.

3. Gudziy N. Maxim the Greek and his Relation to the Era of the pp. 1-19. Dunaev B Reverend Maxim the Greek and the Greek pp. 1-19; Dunaev B. Reverend Maxim the Greek and the Greek
Idea in Russia in the 16 $16^{\text {th }}$ century. Moscow, 1916; Bulanin D. "Maxim the Greek and the Byzantine Literary Tradition." Abstrac of the thesis. Leningrad, 1978; Haney J. From Italy to Moscovy: The Life and Works of Maxim the Greek. Munchen, 1973. Messages Kiev 1901; Gous from A. The Idea of Mosscery and $H$ Messages. Kiev, 1901; Goldberg A. The Idea of «Moscow - the
Third Rome» in a Series of Works of the First Half of the 16 Century. TODRL, vol. 37. Leningrad, 1983, pp. 139-149. 


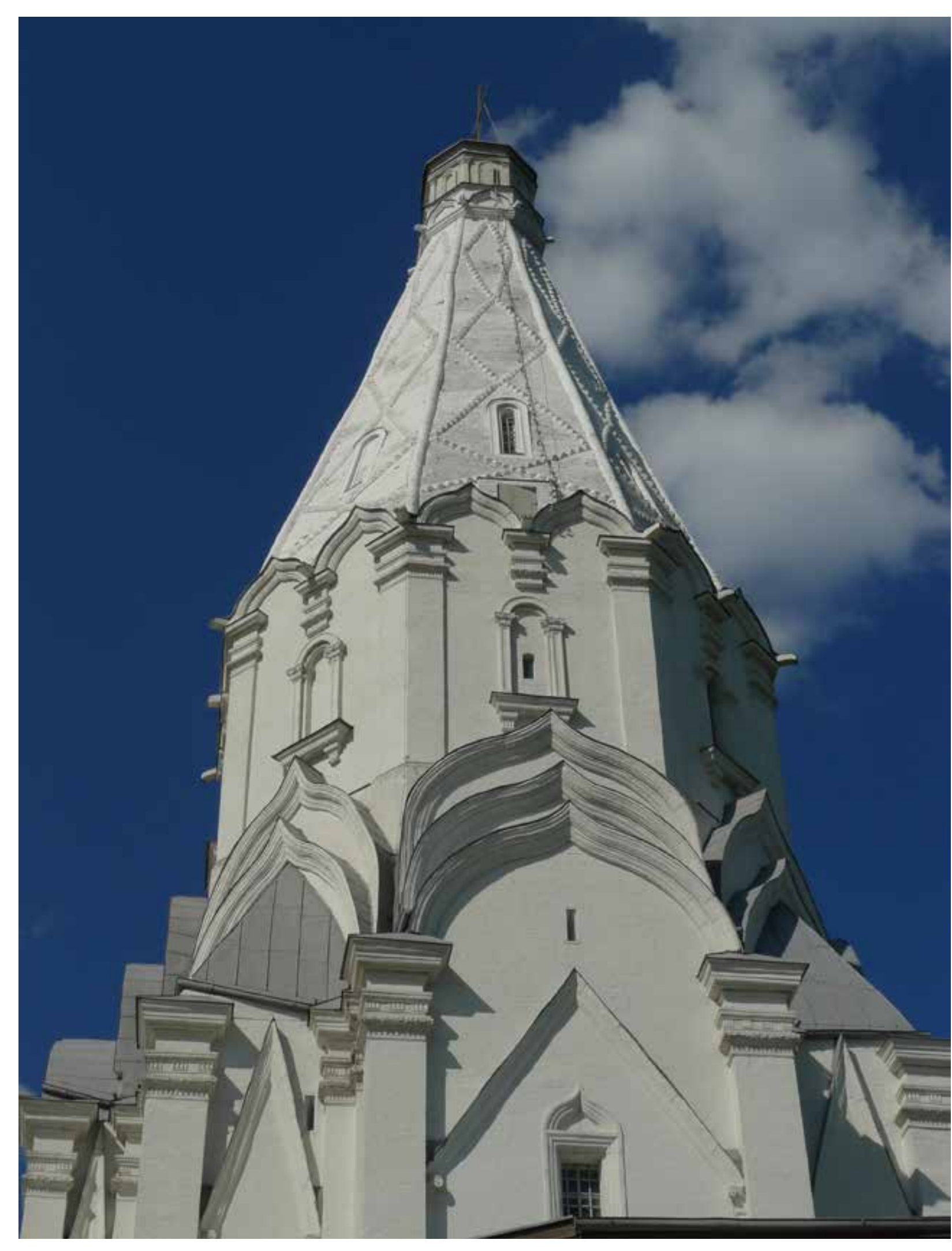

The Church of the Ascension at Kolomenskoye

people from the circle of Vasily III who professed Khristianskiya tsarstva pridosha v konets i sshed the idea of transforming Moscow into a new centre of the Orthodox world. eshesya vo yedino tsarstvo nashego gosudarya to yest' roseyskaye tsarstvo. Dva ubo Rima padoPhilotheus gave this aspiration a formula that sha, a tretiy stoit, a chetvertomu ne byt'... Podobayet
s become classic in Russian culture: "Yako vse
tsarstvuyushchemu derzhati siye s velikim opaseni- yem i k Bogu obrashcheniyem" ${ }^{\prime}$ [As if the entire Christian kingdom came to an end and merged into one kingdom of our sovereign... that is, the Russian kingdom. Two of Romes fell, and the third one is standing (the first is meant to be antique Rome, the second - Constantinople, the third - Moscow author), and there will not be a fourth... It befits a reigning sovereign to keep this with great apprehension and by addressing God]. He considered Vasily III "...presvetleyshim ... gosudarem nashim izhe vo vsey podnebesnoy yedinogo khristianam tsarya brazdoderzhatelya svyatykh bozhikh prestolov svyatyye vselenskiye angel'skiye tserkvi" ${ }^{\prime \prime}[.$. the most gracious... our sovereign in the whole heavenly kingdom, the only Christian king and holder (as guardian and organiser - author) of the holy thrones of God, the holy universal angelic churches]. However, he emphasised the superiority of Moscow both over Rome and Constantinople in religious terms.

At this time, the strengthening of the Grand Duke's power and the development of ideology, which sought to give a new character to the Russian state, continued. During this period, the idea of "Moscow - the Third Rome" was finally expressed. This new ideology is associated with a radical change in the architecture of buildings erected on the orders of Vasily III.

This is evidenced by the most important monument of that era - the Church of the Ascension in the residence of the Great Dukes in Kolomenskoye near Moscow. The date of completion of construction is precisely documented - 1532. The question of who built the church had long been controversial. Today, it is considered proven that Italian architect Pietro Annibale, who was called Petrok Maly ${ }^{7}$ in Moscow, was its author. In 1539, he fled from Russia, which was affected by the turmoil after the death of Vasily III. Vasily's young son Ivan IV, the future Ivan the Terrible, and his widow Elena Glinskaya, weakly connected with the Moscow aristocracy, could not retain power. The Italian master, having lost his primary customer and patron, left for Livonia ${ }^{8}$. There he told the story of his life to the Bishop of Dorpat. He recalled that after the capture of Rome by the troops of Charles V in 1527, there had been many unem-

5. Malinin V. Ibid. Appendix, p. 45

6. Ibid, p. 45 .

Bulkin V. "On the Church of the Ascension in Kolomenskoye" // Culture of Medieval Russia. Moscow, 1976, pp. 113-116 Architecture and Monumental Art. Moscow 1983, pp. 34-40. 8. Svenska Riksarkivet (SRA), Livonica, I, vol. 12 ployed builders in the city. However, the Russian had needed a master who could be both a military engineer and an architect. The choice, on the advice of the pope, had fallen on Pietro Annibal, born in Pisa and serving the papal throne ${ }^{9}$. The details of his biography and origin are especially important since it was this master who made a fundamentally new step in the application of architectural ideas in Russia associated with the attempts to unite Byzantine symbols and architectural ideas of the Italian Renaissance into a single whole. His customer, Vasily III, and he himself decided to move away from the centuries-old tradition of cross-domed structure and create something entirely new. The erection of doubtedly changed the path of development of all Russian architecture of the $16^{\text {th }}-17^{\text {th }}$ centuries. Its forms, particularly the high ceiling in the form of a tent, were very little connected with the preced ing church buildings. In both the 1 th $^{\text {th }}$ and $20^{\text {th }}$ centuries, researchers made many attempts to explain the origin of this church architecture ${ }^{10}$. The source of the composition of the Church of the Ascension in Kolomenskoye was searched for in Italy, Georgia Armenia, Poland. It was associated with "izhe pod kolokoly" [like bells] churches - crowned with bell towers, which were built in Moscow in the $14^{\text {th }}-15^{\text {th }}$ centuries, and most often seen in wooden architecture, represented, alas, only by later monuments. Unfortunately, these explanations do not seem convincing since they indicate only examples of compositions built on the predominance of the vertical or some details that could not determine the general design of the church.

The Church of the Ascension in Kolomenskoye was consciously built as a church-tower. Its height is 62 meters. Inside, there is a very small space, just over 100 square meters. The plan is strictly centred and represents an equal-ended cross. The church

9. Kivimae J. Peter Frjazin or Peter Hannibal? An Italian Architect in Late Medieval Russia and Livonia. // Settentrione. Rivista studi italo-finlandeesi. Anno V. Turku, 1983, pp. 60-69. 10. Sultanov N. "Russian Tent-roofed Churches and Their Relationship to the Georgian-Armenian Pyramidal Ceilings". Proceedings of the $V$ Archaeological Congress in Tiflis.
Moscow, 1887: Nekrasov A "Problem of the Origin of Ancien Russian Pillar-like Churches" // Proceedings of the Cabinet of the History of Material Culture. Issue 5. Moscow, 1930; Rogovin N. Church of the Ascension in Kolomenskoye. Moscow, 1941; Gra M., Zheromsky G. Kolomenskoe. Moscow, 1970; Bulkin "On the Church of the Ascension in Kolomenskoye". Culture Architecture. Monuments of the Mid-16 $6^{\text {th }}$ Century. Moscow 
is surrounded by a gallery with three staircases, repeating the shape of its plan. On the facade, all corners are marked with elongated flat pilasters with light capitals. Surprisingly, pointed Gothic gables with the tops set on the level of the capitals are placed between the pilasters.

An octahedron is placed on the main cruciform volume of the church. At the top, there are rows of large keeled arches, traditional for the Moscow architecture of that time. An octahedron with classic double pilasters at the corners and windows in the middle of the edges is above them. The church is crowned with a high ceiling in the form of an octahedral tent with clearly defined ribs.

For the Russian tradition of that period, every thing is unusual here: the vertical composition of such scale, the centric form of the plan, even without the obligatory apses in the altar part, the nature of the details. However, what is most essential for us is the clearly expressed monumentality, the inability of the church to accommodate a large number of people during the service. Only a limited number of people could take part in it, insignificant compared to the grandiose size of the structure. This indicates that the church's composition is, first of all, an expression of a certain ideological concept, and is not based on any functional idea.

A distinct combination of Renaissance Italian elements, Gothic motifs, perhaps also Italian, traditionally Moscow features is also important. Here, the primary role was played by the principles of composition associated with the Italian Renaissance. Pietro Annibale chose the type of plan in the form of a Greek cross, which was considered ideal for a church in Italy in the early $16^{\text {th }}$ century. Rudolf Wittkowe mentions that, according to the ideas of that period, it combined the symbol of the cross and the symbolic values of centric geometry ${ }^{11}$. Based on the opinion of the researcher, we have to admit that the Italian master chose the most common plan for the Church of the Ascension, such as would have been used by many Italian architects of the early $16^{\text {th }}$ century for a church of such an "ideal" or "ideologised" purpose. The idea of surrounding the building with an open gallery was equally "normal" for the Italian master. Unexpectedly, two elements distinguish the Church of the Ascension in Kolomenskoye from the Italian buildings with a plan in the form of a Greek cross. First of all, the use of a pyramidal roof in the form of a tent instead of a dome. And the second less noticeable element is a monumental throne on the gallery, which is attached to the church's eastern wall from the outside and turned "with its back" to the altar

Questions about the origin and meaning of the tent and the throne of the Church of the Ascension are among the most controversial mysteries in the history of Russian architecture of the early $16^{\text {th }}$ century. Let us try to find one answer to both of these questions at once, to find a connection between the creation of a completely unusual shape of the roo and the more than strange placing of the throne "back" to the altar.

It seems that the explanation can be found in the dedication of the church in Kolomenskoye to the Ascension of Christ. The pyramidal tent in its shape resembles a ciborium - a canopy over a relic or altar, which had been well known to Russians for several centuries before. Images of pyramidal ciborium have been known in Russia since the $11^{\text {th }}$ century and were used in the $16^{\text {th }}$ century.

Somewhat later than the Church of the Ascension "Tsarskoe Mesto" - the throne for the prayer of the sovereign, which belonged to Ivan IV the Terrible, in the church with a similar crown was preserved in the Assumption Cathedral of the Moscow Kremlin ${ }^{12}$. The aspiration of Vasily III and his Greek-Moskow circle to create a symbol of the transfer of the shrine of the Church of Constantinople to the Russian land could be of significant importance. St. Sophia of Constantinople could have served as such symbol. In Russia, there was a tradition of dedicating cathedrals to St. Sophia; however, this was never expressed in specific architectural details. Perhaps it was due to the technical impossibility and, therefore, inconceivable reproduction of the grandiose church and its complex structures. However, for the $16^{\text {th }}$ century, with its heightened sense of a model, the concretenes of the reproduced image was necessary.

In this regard, the coincidence of the construc tion of the church in Kolomenskoye and the grandiose ciborium that existed above the altar of St. Sophia, which was described in detail by St. Herman Patriarch of Constantinople in the $8^{\text {th }}$ century, seems significant. This description has been known in Rus-

12. Uvarov A. Small works. T.. Moscow, 1910. P. 290; Pokrovsky N. "Jerusalem or Zion of the St.Sophia Sacristy in Novgorod" // Bulletin of Archaeology and History. Issue XXI. St.Petersburg, the Moscow Assumption Cathedral" "Monuments of Russian Architecture and Art. Moscow, 1985, pp. 39-57. sia for a long time and, possibly, owing to the later text of the blessed Simeon of Thessalonica from the beginning of the $15^{\text {th }}$ century, which was established by P.Lashkarev ${ }^{13}$, professor of the Kiev Theological Academy, back in the $19^{\text {th }}$ century. St. Herman said: "...kivoriy, gde sovershayetsya samo raspyatiye zastupayet mesto, na kotorom raspyat Khristos ... izobrazhayet on soboyu takzhe i kivot zaveta Gospodnya"14 [the ciborium, where the crucifixion itself takes place (symbolically - author), takes over the place where Christ was crucified... it also represents the ark of the covenant of the Lord]. Further the holy patriarch tells about the building, located in the huge inner space of the church of St. Sophia in Constantinople and which capture of the capital of Byzantium by the crusaders in 1204 during the existence of the Latin Empire.

The author's description of St. Sophia says that in it "... resting on silver arches on four sides, an immeasurably high tower rises above the altar into vast airspace... Above the arches, something similar to a cone rises, but not quite like it since from the very bottom, it does not maintain a regular circle at its base but a certain eight-sided base, which one-pointedly rises little by little up... forming long edges. Similar to triangles, these planes... unite into one, a pointed peak... On this peak, art has displayed an image of a chalice... Above the arches, a patterned belt of pointed curls frame the lowest base of the cone..$^{15}$ It is difficult to imagine how accurate the description of the church top, unusual for Russia in Kolomenskoye was.

In Kolomenskoye, a grandiose ciborium was erected over the entire church, glorifying the dedication to the Ascension of Christ, creating an architectural mage of this sacred event. It is important to note that the Ascension of Christ is directly related to his Second Coming. It is at the moment of the Ascension that the expectation of the return of God to earth begins. However, the Second Coming was to be prepared by the triumph of the Christian kingdom on earth. As we have already mentioned, Russian theologians of the beginning of the $16^{\text {th }}$ century called the last "kingdom awaiting the end of time" the "Third Rome" and identified it with the Moscow state. Perhaps it is in this context that the arrangement of the throne with its back to the alta

13. Quoted from Lashkarev P. Ciborium as a Distinctive Feature of the Altar in an Ancient Church. Kiev, 1883, p. 6. 14. Ibid, p.8. and its removal from under the ciborium becomes understandable.

The ciborium glorifies an event that already occurred - the Ascension of Christ. The throne is symbolic, awaiting the Second Coming of Christ. The placement of the throne to the east of the altar, behind it, was probably associated with the desire to transfer it to the future, to the "other world" that would arise after the Second Coming. The combination of the glorification of the Ascension, the creation of its symbolic embodiment in the form of ciborium over an equal-pointed cross, the expression of eschatological expectations - the erection of a throne awaiting the return of Christ, testifies to the fact that the church in Kolomenskoye marks the establishment of the mystical centre of the Orthodox kingdom in Russia. The church became an architectural symbol that would exist "until the end of time" - during the reign of the Third Rome, af ter which, according to monk Philotheus, "there will be no fourth"

Thus, perhaps, master Pietro Annibale combined the "architectural ideology" of the centric churches of Italy of the beginning of the $16^{\text {th }}$ century with the exchatolic program of the court circle of Vasily III. It expressed both the shock of taking control of Constantinople by the faithless from the "last Byzantines", close ones and relatives of Vasily III, and the reaction to this event in Moscow, the desire to transfer the symbolic center of the Orthodox world to Russia. The symbolism of this church reflects the political aspirations characteristic of Russia in the $15^{\text {th }}$ and $16^{\text {th }}$ centuries. The emerging centralised state, the Muscovite kingdom, needed to express its ideology, affirming the legality, God's chosenness and the highest authority of the power that reigned in it. Essentially, a visible image of this power was needed - a new one, convincing of its greatness.

The walls and towers of the Kremlin, its main palace and the most important cathedrals con veyed these symbols in their forms. An unusual character, different from the usual images of Moscow architecture, ensured their participation in forming a new image of the power of the Moscow sovereigns, comparable to the status of the Byzantine basileus. The symbolism of the Church of the Ascension in Kolomenskoye is another step in developing the architectural ideology of the Russian kingdom. It was already an attempt to create a symbol that would make it possible to comprehend the nature of the new state, to con- 
vey its ideal. The architecture of the Church of the Ascension in Kolomenskoye became part of the idea of an ideal state, an expression of the new ideology of the Third Rome.

The artistic discoveries of that time, when masters from Renaissance Italy were working in Moscow, were the basis for the further development of Russian architecture of the $16^{\text {th }}-17^{\text {th }}$ centuries. With their participation, a purely Russian, very peculiar type of architectural ideology arose. It was expressed in forms associated with the Italian Renaissance. And at the same time, it included "quotes" from ancient Russian buildings and images born of memories of Byzantium. Architectural thinking appeared in Russia, which, perhaps, should be defined as the artistic mentality of the "eschatological Renaissance" or "Renaissance of the last kingdom", which would remain "until the end of time".

It is important that, despite their religious nature, these ideas were ideas of the state and not only of the church. They created precisely the state architectura symbolism that glorified the royal power in the spirit of its symphony with the church's life. It was widely

REFERENCES

1. Batalov, A.L., Beliayev, L.A. 2013. Tserkov Voznesseniya $v$ Kolomenskom: arhitektura, arheologiya, istoriya ya $v$ Kolom

2. Bocharov, G.N. 1985. "Tzarskoye mesto Ivana Groznogo v Moskovskom Uspenskom sobore", Pamiatniki Russkoy arhitectury i iskusstva,

3. Bulanin, D. 1978. Maksim Grek I vizantiyskaya literaturnaya traditziya. Avtureferat dissertaziii.. Leningrad 4. Bulkin, V. 1976. "O tzerkvi Vozneseniya v Kolomenskom", Kultura Srednevekovoy Rusi, Moscow.

5. Gra, M., Jeromsky, G. 1970. Kolomenskoye, Moscow

6. Gudziy, N. 1911. "Maksim Grek i ego otnoshenie k epohe italyanskogo Vozrogdeniya. Kiev", Universitetskie izvestiya, no. 7 .

7. Dunaev, B. 1916. Prepodobniy Maksim Grek i grecheskaya ideia na Rusi v XVI veke. Moscow

Il'in M. Russkoye shatrovoye zodchestvo. Pamiyatnik serediny XVI veka. Moscow, 1980

9. Haney, J. 1973. From Italy to Moscovy: The Life and Works of Maxim the Greek. Munchen

10. Kivimae, J. Peter Frjazin or Peter Hannibal? An Italian Architect in Late Medieval

. Russia and Livonia. Settentrione. Rivista di studi italofinlandeesi. Anno V. Turku, 1983.

12. Lashkarev P. 1883. Kivoriy kak otlichitelnaya prinadlegnost altaria $v$ drevney tserkvi. Kiev used in royal buildings of the $16^{\text {th }}$ and $17^{\text {th }}$ centuries The motifs brought by Italian masters at the begin ning of the Renaissance undoubtedly underwent significant transformations in Russia for centuries and "survived" until the era of Peter the Great.

In the Church of the Ascension in Kolomenskoye, one can observe an example of the desire of the state authorities to create an artistic system of church architecture using elements of various origins. This new "style" in Russian church architecture is based on the principles brought by Italian masters, which are combined with the desire for increased expres siveness and vertical composition, a pronounced decorativeness of the late Middle Ages. The techniques used for the first time in the Church of the Ascension in Kolomenskoye would be used in the erection of tent-roofed churches during the subsequent history of our building art. However, the semantic connotations associated with Constantinople would subsequently be replaced by Jerusalem ones, and later by a system of memorial meanings reflecting the meanings of the victories of Ivan the Terrible and approval of the first Romanovs in power.

13. Malinin, V. 1901. Staretz Elizarieva monastyria Filofei ego poslaniya. Kiev,

4. Miller, D. 1978. "The Lubeckers Bartholomaus Ghotan and Nicolas Bulow in Novgorod and Moscow and the Problem of Early Western Influences on Russian Culture", Viator, no.9.

5. Nekrasov A. 1930. "Problema proishogdenia drevnerusskyh stolpoobraznyh hramov", Trudy Kabneta istoril materialnoy kultury, vol. 5, Moscow 16. Podyapolskiy, S. 1983. "Arhitektor Petrok Maly", Pam atniki russkoi arhitektury i iskusstva. Moscow

17. Pokrovsky, N. 1911. "Ierusalim ilt Sion Sofiyskoy riznitzy v Novgorode", Vestnik aeheologii i istorii, vol. XXI, Sain Petersburg

18. Rossiyskaya istoricheskaya biblyoteka. vol. 6, tch,1. Sain Petersburg, 1908

9. Slovar knignikov i knignosty Drevney Rusi. Vtoraya polovina XIV - XVI vekov. Tch.I. Leningrad, 1988.

20. Sultanov, N. 1887. "Russkiye shatrovie tzerkvi I in sootnoshenie $s$ gruzinsko-armianskimi pyramedalnimi pokritiyami", Trudy V Arheologicheskogo s"ezda v Tiflise, Moscow

21. Wittkower, R. 1973. Architectural Principles of the Age of Humanism. London

Николай Александрович Коротае доцент, заместитель заведующего кафедрой «Храмовое зодчество Московского архитектурного института (Государственной академии) e-mail: nikolyasarkozi@inbox.ru Москва, Россия

DOI: $10.36340 / 2071-6818-2021-17-3-10-23$

ORCID 0000-0003-2810-9705

\section{СМЫСЛ ШАТРА В АРХИТЕКТУРЕ «РУССКОГО РЕНЕССАНСА» XVI СТОЛЕТИЯ ${ }^{1}$}

Аннотация: Статья нацелена на прояснение Анвоначального смысла шатрового храмового перекрытия как кивория исходя из потребности осмысленной, опирающейся на традицию интер претации этой художественной формы церковными архитекторами России XXI века.

В статье рассматривается вопрос о происхождении формы шатра, исходя из культурного контекста периода, в который он появился в ар хитектуре России, и его символического смысла восходящего к традициям эпохи раннего христианства. В течение научной дискуссии, ведущейся на протяжении полутора веков, высказывались самые различные мнения о генезисе шатрового перекрытия: его связывали с традициями русского деревянного зодчества, с влиянием армянской, грузинской и даже индийской строительных традиций. В статье подробно рассматривается культурологический контекст возникновения первого каменного шатра в русской архитектуре - в церк- ви Вознесения в селе Коломенском, построенной по заказу великого князя Василия III. Точно документируется дата окончания строительств церкви - 1532 год. Вопрос о том, кто возвёл церковь, долгое время был дискуссионным. Сегодня считается достоверно доказанным, что ее автор - итальянский архитектор Пьетро Аннибале ди Пиза, которого в Москве называли Петрок Малый и который в 1539 году бежал из Руси, охваченной волнениями, наступившими после смерти Василия III

В статье прослеживается связь символического смысла шатра с идеями Москвы как Нового Константинополя и Третьего Рима. Авторы утверждают совпадение форм подмосковного храм с описаниями кивория, располагавшегося в храме св. Софии в Константинополе. Эти описания представлены в текстах Св. Германа, патриарха Константинопольского, и были известны в России XVI века. Авторы утверждают, что символика 
церкви Вознесения в Коломенском - ещё один шаг в развитии архитектурной идеологии русского царства. В нём заключена попытка создать символ, позволяющий осмыслить характер нового государства, передать его идеал. Архитектура церкви Вознесения в Коломенском стала частью представлений об идеальном государстве, выра-

Проблема возникновения формы шатрового завершения русских храмов очень давно и подробно рассмотрена в историографии, которая в полной мере отражена в последней книге А.Л. Баталова и Л.А. Беляева, посвящённой церкви Вознесения в селе Коломенском. В этой статье мы пытаемся показать первоначальный смысл шатра как кивория, исходя из потребности осмысленной, опирающейся на традицию интерпретации этой художественной формы церковными архи текторами России XXI века.

В 1492 году православный мир ожидал конца света. По летоисчислению, которое велось от предполагаемой даты сотворения мира, в этот момент заканчивалось седьмое тысячелетие. Когда 7000 год благополучно прошёл, ожидание вселенской катастрофы сменилось стремлением определить длительную историческую перспективу, увидеть черты будущего.

Митрополит Зосима выступил в Москве с но вым календарём основных церковных праздни ков - пасхалией. В своём изложении пасхалии «... на осьмую (восьмую. - Авт.) тысячу лет... в ней же часы... пришествия Христова» он высказал мысли развивавшие представления Св. митрополита Ионь о русской церкви как о средоточии «прежнего греческого богоустановленного благочестия». Причем теперь речь шла уже о перенесении на русскую почву идей империи праведного христианского царства. «И ныне же... прослави Бог... благоверного и христолюбивого великого князя Ивана Васильевича (Ивана III. - Авт.), государя и самодержца всея Руси, нового царя Константина новому граду Константину Москве». ${ }^{1}$ И ранее в летописях русские государи часто сравнивались с императором Константином. Однако в произведении митрополита Зосимы появилось существенное новшество Москва для него не просто «новый Константинополь», не только центр православного мира. Она

1. Российская историческая библиотека. Т. 6, ч. 1. СПб., 1908 №. 118, стб. 795-796; Зосима, митрополит всея Руси // Сло

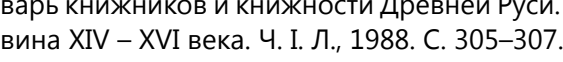

жением новой идеологии Третьего Рима, сфор мулированной старцем Елизарьева монастыр под Псковом Филофеем в первой четверти XVI столетия.

Ключевые слова: архитектура России, происхождение формы, смысл формы, Ренессанс.

- последняя его столица, которая должна просу ществовать до Второго пришествия Христа.

Подобные мысли, которые возникли в конце периода правления Ивана III, стали основой политических представлений, господствовавших в Москве при Василии III и определивших особенности использования архитектурных идей русского Ренессанса. Русская мысль все ближе подходи к представлению о Москве не как о новом Кон стантинополе, но как о «Третьем Риме», последней империи, которая «пребудет до скончания века».

В течение правления Василия III в Москве развернулась ожесточённая дискуссия на эту тему, повлиявшая на развитие русской архитектуры. Так, 1508 году в Москве появился приехавший из Германии Николас Булев, знаток медицины и астрологии, «основательнейший во всех науках». ${ }^{2}$ Вскоре став придворным врачом, он быстро превратился в одного из ближайших собеседников великого князя Василия III. Немецкий учёный был сторонником «Первого Рима» - соединения идей империи и представления о главенстве в христианском мире папского престола. Кроме того, он верил распространённое тогда в Германии предсказание о наступлении конца света в 1524 году.

Это противоречило мечте последних византийцев и их московских сторонников о создании на Руси последнего православного царства. Против Николаса Булева выступили и те, и другие. Значительную роль в этих спорах сыграл византийский гуманист Максим Грек. ${ }^{3}$ Эмигрировав в Италию, он сотрудничал там с Иоанном Ласкарисом и Джованни Франческо Пико делла Мирандола, затем, разочаровавшись в католицизме, переехал жить

2. Miller D. The Lubeckers Bartholomaus Ghotan and Nicolas Bulow in Novgorod and Moscow and the Problem of Early Western

3. Гудзий Н. Максим Грек иего отношение кэпохе итальянского Возрождения. Киев. Университетские известия, 1911, №. 7 , c. 1-19; Дунаев Б. Преподобный Максим Грек и греческая иден на Руси в В ИІ веке. М., 1916, Буланин Д. Максим Грес и византийская литературная традиция. Автореферат дис-
сертации ... .. 1978; Haney J. From Italy to Moscovy: The Life and Works of Maxim the Greek. Munchen, 1973. на Афон, а в 1516 году переселившись в Москву, вступил в спор с немецким медиком, доказывая превосходство византийской православной традиции. Накануне предполагавшегося германски астрологами конца света в 1523-м или в 1524 году его поддержал монах Филофей в своём знамени том послании «на звездочетцев». Трактат старца из Елизарьева монастыря под Псковом ${ }^{4}$ был близко связан с московской придворной жизнью, что его появление, вероятно, спровоцировали те лица из окружения Василия III, которые исповедовали идею превращения Москвы в новый центр православного мира.

Филофей придал этому стремлению формулу, ставшую классической в русской культуре: «Яко все Христианския царства придоша в конец и сшедешеся во едино царство нашего государя ...то есть росейскае царство. Два убо Рима падоша, а третий стоит (имеется в виду первый собственно античный Рим, второй Рим -Константинополь, третий - Москва. - Авт.), а четвертому не быть.. Подобает царствующему (государю. - Д.Ш.) держати сие с великим опасением и к Богу обращением». ${ }^{5}$ Василия III он считал «...пресветлейшим ... государем нашим иже во всей поднебесной единого христианам царя и браздодержателя (как охранителя и устроителя. - Д.Ш.) святых божих престолов святые вселенские ангельские церкви». ${ }^{6}$ Впрочем, он подчёркивал превосходство Москвы в религиозном отношении и над Римом и над Константинополем.

В это время продолжалось укрепление власти великого князя и развитие идеологии, стремившейся придать новый характер русскому государству. Именно в этот период получила окончательное выражение идея «Москва - Третий Рим». С этой новой идеологией связано радикальное изменение архитектуры зданий, возводившихся по заказам Василия III.

Об этом свидетельствует наиболее важный памятник той эпохи -церковь Вознесения подмосковной резиденции Великих князей в Коломенском. Точно документируется дата окончания строительства - 1532 год. Вопрос в том, кто возвёл церковь, долгое время был дискуссионным. Сегодня считается доказанным, что ее

4. Малинин В. Старец Елизарова монастыря Филофей и его послания. Киев, 1901; Гольдберг А. Идея «Москва - Тре Тий Рим» в цикле сочинений первой половины XVI века.
ТОДРЛ, т. 37. Л., 1983. С. 139-149. Малинин В. Указ соч. Приложение. С. 45.

5. Малинин В.У.
6. Там же. С. 45 . автор - итальянский архитектор Пьетро Анни бале, которого в Москве называли Петрок Малый. ${ }^{7}$ В 1539 году он бежал из Руси, охваченной летний сын Иван IV, будущий Иван Грозный, вдова Елена Глинская, слабо связанная с московской аристократией, не могли удержать власть. Итальянский мастер, лишившись своего главного заказчика и покровителя, уехал в Ливонию. ${ }^{8}$ Там он рассказал историю своей жизни епископу Дерпта. Он вспоминал, что после взятия Рима войсками Карла V в 1527 году в городе было немало безработных строителей. Русским однако, был необходим мастер, который мог бы быть одновременно военным инженером и архитектором. Выбор, по совету папы, выпал на Пьетро Аннибале, родившегося в Пизе и бывшего на службе папского престола. ${ }^{9}$ Подробно сти его биографии и происхождение особенно важны, потому что именно этот мастер сделал принципиально новый шаг в применения на Руси архитектурных идей, связанных с попытками объединить в единое целое византийские символь и архитектурные идеи Ренессанса Италии. Его заказчик Василий III и он сам решились отойти от многовековой традиции крестово-купольных сооружений и создать нечто совершенно новое Возведение церкви Вознесения в Коломенском, безусловно, изменило путь развития всей русской архитектуры XVI-XVII веков. Её формы, прежде всего высокое перекрытие в виде шатра, были очень мало связаны с предшествовавшими церковными постройками. И в XIX, и в XX столетия исследователями было предпринято множество попыток объяснить происхождение архитекту Ры этого храма 10 Искали источник композиции церкви Вознесения в Коломенском в Италии 7. Булкин В. О церкви Вознесения в Коломенском // Культура Средневековой Руси. М., 1976. С. 113-116; Подьяпольский С. Архитектор Петрок Малый. Памятники русской архитекSvenska Riksarkivet (SRA), Livonica, I, vol. 12.

Kivimae J. Peter Frjazin or Peter Hannibal? An Italian Architect in Late Medieval Russia and Livonia // Settentrione. Rivista studi italo-finlandeesi. Anno V. Turku, 1983. P. 60-69,

уултанов Н. Русские шатровые церкви и их соотношение грузинско-армянским пирамидальными покрытиям // Тру
ды V Археологического съезда в Тифлисе. М. 1887: Некрасов А. Проблема происхождения древнерусских столпообразных храмов // Труды Кабинета истории материальной культуры. Вып. 5. М., 1930; Роговин Н. Церковь Вознесения в Коломенском. М., 1941; Гра М., Жеромский Г. Коло менское. М., 1970; Булкин В. О церкви Вознесения в Коло М. Русское шатровое зодчества. Памятники середины XV века. М., 1980. 
Грузии, Армении, Польше. Связывали её с церквями «иже под колоколы», то есть увенчанными колокольнями, которые строились в Москве XIV-XV веков, а чаще всего видели в деревянной архитектуре, представленной, увы, лишь более поздними памятниками. К сожалению, эти объяснения не представляются убедительными, поскольку указывают лишь на примеры композиций, построенных на преобладании вертикали или на некоторые детали, которые не могли определить общий замысел храма.

Церковь Вознесения в Коломенском осознано построена как храм-башня. Её высота 62 метра. Внутри же неё - очень небольшое пространство, немногим более 100 квадратных метров. План строго центричен и представляет собой равноконечный крест. Храм опоясывает галерея с тремя лестницами, повторяющая форму его плана. На фасаде все углы отмечены вытянутыми плоскими пилястрами с лёгкими капителями. Удивительно то, что между пилястрами сделаны остроконечные готические вимперги с вершинами, поставленными на уровень капителей.

На основной крестообразный объём церкви поставлен восьмигранник. Вверху по нему тянутся ряды больших традиционных для московской архитектуры того времени килевидных арок. Над ними - восьмигранник со сдвоенными класси ческими пилястрами по углам и окнами в середине граней. Венчает храм высокое перекрытие в виде восьмигранного шатра с чётко выделенными рёбрами.

Для русской традиции того периода здесь необычно буквально всё. Сама вертикальная композиция такого масштаба, центрическая форма плана, даже без обязательных абсид в алтарной части, характер деталей. Но более всего для нас важны ярко выраженная монументальность, неприспособленность храма вместить сколько-нибудь большее число людей во время богослужения. В нём могло принимать участие лишь ограниченное число лиц, незначительное в сравнении с грандиозными размерами сооружения. Это свидетельствует о том, что композиция церкви является прежде всего выражением определённой идеологической концепции, а не основана на какой-то функци ональной идее.

Важно также отчётливое соединение ренессансных итальянских элементов, мотивов готики, возможно также итальянской, традиционно московских черт. Главную роль здесь всё же играли принципы композиции, связанные с итальянским Возрождением. Пьетро Аннибале избрал тип плана в форме греческого креста, считавшийся идеальным для церкви в Италии начала XVI века. Рудольф Виттковер упоминает, что в нём соединились, по представлениям того периода, символ креста и символические ценности центрической геометрии. ${ }^{11}$ Исходя из мнения этого исследователя, приходится признать, что итальянский мастер выбрал для церкви Вознесения самый обычный план, такой как применили бы многие архитекторы Италии начала XVI века для храма подобного «идеального» или «идеологизированного» назначения. Столь же «нормальным» для итальянского мастера была мысль окружить здание открытой галереей. Неожиданным, тем, что отличает церковь Вознесения в Коломенском от итальянских построек с планом в форме греческого креста, являются два элемента. Прежде всего, применение пирамидального перекрытия в виде шатра вместо купола. И второй, менее заметный элемент: монументальный трон на галерее, который приставлен к восточной стене церкви снаружи и повёрнут «спиной» к алтарю.

Вопросы о происхождении и смысле шатра и трона церкви Вознесения относятся к числу наи более спорных тайн истории русской архитектур бачала XVI века. Попробуем найти один овтуры оба этих вопроса сразу. Попытаемся найти связ между созданием впервые совершенно необычной формы кровли и более чем странной постановкой трона «спиной» к алтарю.

Кажется, что объяснение можно найти в посвящении храма в Коломенском Вознесению Христа. Пирамидальный шатёр по своей форме напоминает киворий - балдахин над реликвари ем или алтарём, который был хорошо известен русским уже на протяжении нескольких веков. ны в России с XI века и применялись они в XVI столетии.

Несколько более позднее, чем церковь Вознесения, «Царское место» - трон для молитвы государя в церкви с подобным завершением, принадлежавший Ивану IV Грозному, сохранился в 11. Wittkower R.Architectural Principles of the Age of Humanism. Wittkower R. Architectu
London, 1973. C. 13-21.
Успенском соборе Московского Кремля. ${ }^{12}$ Существенное значение могло иметь стремление Василия III и его греко-московского окружения создать символ перенесения святыни константинопольской церкви на русскую землю. Таким символом могла служить Св. София Константинопольская. На Руси существовала традиция посвящения кафедральных храмов Св. Софии, но это никогда не выражалось в конкретных архитектурных цитатах. Вероятно, - в силу технической невозможности и поэтому немыслимости воспроизведения грандиозного храма и его сложных конструкций. Однако для XVI века с его обострённым чувством образца была необходима конкретность воспроизводимого образа.

В связи с этим представляется знаменательным совпадение построения церкви в Коломенском и грандиозного кивория, существовавшего над алтарем Св. Софии, который подробно описал Св. Герман, патриарх Константинопольский в VIII веке. Это описание было с давних пор на Руси известно само по себе и, возможно, благодаря более позднему тексту блаженного Симеона Солунского начала XV века, что было установлено еще в XIX столетии профессором Киевской духовной академии П. Лашкарёвым. ${ }^{13}$ Св. Герман писал: «..киворий, где совершается (символически. - Д.Ш.) само распятие, заступает место, на котором распят Христос... изображает он собою также и кивот завета Господня». ${ }^{14}$ Далее святой патриарх рассказывает о сооружении, находившемся в огромном внутреннем пространстве храма Св. Софии в Константинополе и исчезнувшем после захвата столицы Византии крестоносцами в 1204 году в период существования Латинской империи.

Описание автора Св. Софии гласит, что в ней «...над алтарём поднимается в обширное воздушное пространство неизмеримо-высокая башня опирающаяся на серебряные на четыре стороны арки... Выше арок встаёт нечто подобной конусу, но не совершенно на него похожее, потому что с самого низу не выдерживает в основании своем правильного круга, но образуется некоторый

12. Уваров А. Мелкие сочинения. Т. І. М., 1910. С. 290; Покровский Н. Иерусалим или Сион Софийской ризницы в Новгороде // Вестник археологии и истории. Вып. ХXI. СПб,
1912; Бочаров Г.. Царское место Ивана Грозного в Мо1912; Бочаров Г.Н. Царское место Ивана Грозного в Мо-
сковском Успенском соборе // Памятники русской архисковском Успенском соборе // Памятники русской архи-
тектуры и искусства. М., 1985. С. 39-57.

13. цит. по Иашуства. M, 1985. П. 39-57.

1. Цит. по Лашкарев П. Киворий как отличительная прин

14. Тамн же. С. 8 . восьмисторонний базис, который из широкого поднимается мало помалу вверх остроконечно. образуя длинные грани... Похожие на треугольное остроконечной вершине На этой вершине искусство выставило изображение чаши... Сверху арок узорной пояс из остроконечных завитков обрамляют самое нижнее основание конуса». Сложно представить себе, насколько было точное описание необычного для Руси завершения церкви в Коломенском.

В Коломенском был возведён грандиозный ки ворий над всем храмом, прославляя посвящение Вознесению Христа, создав архитектурный образ этого священного события. Важно отметить, что Вознесение Христа непосредственно связано с его Вторым Пришествием. Именно в момент Вознесения начинается ожидание возвращения Бога на землю. Однако Второе Пришествие должно было быть приготовлено торжеством на земле христианского царства. Это последнее «царство, жду щее окончания веков», как мы уже упоминали русские теологи начала XVI века называли «Тре тьим Римом» и отождествляли его с Московским государством. Возможно, именно в данном контексте становится понятным устройство трона спиной $\mathrm{k}$ алтарю и вынесение его из-под кивория.

Киворий прославляет уже произошедшее событие - Вознесение Христа. Трон - символический престол, который ждёт Второго Пришествия Христа. Размещение трона восточнее алтаря, за ним вероятно, было связано с желанием как бы перенести его в будущее, в «мир иной», кото рый возникнет после Второго Пришествия. Совмещение прославления Вознесения, создание его символического воплощения в виде кивория над равноконечный крестом, выражения эсхатологических ожиданий - возведения престола, ждущего возвращения Христа, свидетельствует о том, что церковь в Коломенском знаменует собой утверждение на Руси мистического центра православного царства. Храм становится архитектурным символом, который будет существо вать «до скончания веков» - во время царств Третьего Рима, после которого, по мнению монаха Филофея, «Четвертому не быть».

Так, возможно, мастер Пьетро Аннибале соединил «архитектурную идеологию» центрических храмов Италии начала XVI века с эсхатолической

15. Там же. С. 8. 
программой придворного круга Василия III. Она выражала и шок от взятия Константинополя неверными у «последних византийцев», приближённых и родственников Василия III, и реакцию на это событие в Москве, стремление к перенесению на Русь символического центра православного мира. В символике этой церкви сказываются политические стремления, характерные для Руси XV-XVI веков, Возникающее централизованное государство - Московское царство - нуждалось в выражении своей идеологии, утверждающей законность, богоизбранность и высший авторитет господствовавшей в ней власти. По существу, был необходим зримый образ этой власти - но вый и убеждающий в её величии.

Стены и башни Кремля, его главный дворец и наиболее важные соборы передавали эти символь своими формами. Необычный характер, отстранённый от привычных картин московской архитектуры, обеспечивал их участие в формировании нового образа власти московских государей, сопоставимой со статусом византийского базилевса. Символика церкви Вознесения в Коломенском - ещё один шаг в развитии архитектурной идеологии русского царства. Это уже попытка создать символ, позволяющий осмыслить характер нового государства, передать его идеал. Архитектура церкви Вознесения в Коломенском стала частью представлений об идеальном государстве, выражением новой идеологии Третьего Рима.

На художественных открытиях этого времени когда в Москве работали мастера из ренессансной Италии, основывалось дальнейшее развитие русской архитектуры XVI-XVII веков. При их участии возник чисто русский, весьма своеобразный тип архитектурной идеологии. Она выражалась в формах, связанных с итальянским Возрожденим. И в то же время включала в себя и «цитаты из древних русских построек, и образы, рождён-

БИБЛИОГРАФИЯ

1. Баталов А.Л., Беляев Л.А. Церковь Вознесения в Ко- 4. Булкин В. О церкви Вознесения в Коломенском // ломенском: архитектура, археология, история. - М 2013.

2. Бочаров Г.Н. Царское место Ивана Грозного в Мо сковском Успенском соборе // Памятники русской архитектуры и искусства. -М., 1985.

3. Буланин Д. Максим Грек и византийская литературная традиция. Автореферат диссертации ... Л., 1978. ные воспоминаниями о Византии. На Руси появи лось архитектурное мышление, которое, может быть, следует определить как художественную ментальность «эсхатологического Ренессанса или «Ренессанса последнего царства», которое пребудет «до скончания века

Важно, что, несмотря на свой религиозный характер, эти идеи были идеями государства, а не только церкви. Они создали именно государственную архитектурную символику, прославлявшую царскую власть в духе её симфонии с жизнью церкви. Её широко использовали в царских постройках XVI и XVII веков. Мотивы, принесённые

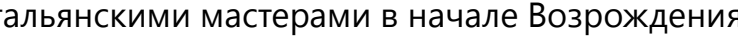
безусловно, в течение столетий переживали в России существенные трансформации, которые «дожили» до эпохи Петра Великого

В церкви Вознесения в Коломенском можно наблюдать пример стремления государственной власти к созданию художественной системы цер ковной архитектуры с использованием разнообразных по своему происхождению элементов. В основе данного нового «стиля» в русском храмовом зодчестве лежат принципы, принесённые итальянскими мастерами, которые соединяютса со стремлением к повышенной выразительности и вертикальной композиции, ярко выраженной декоративности позднего Средневековья. Использованные впервые в церкви Вознесения возведении шатровых храмов в течение последуощей истории нашего строительного искусства но смысловые коннотации, связанные с Константинополем, будут впоследствии заменены на иерусалимские, а позже на систему мемориальных смыслов, отражающих значения побед Ивана розного и утверждения у власти первых Романовых. в Коломенском приёмы будут применяться при

5. Гра М., Жеромский Г. Коломенское. - М., 1970.

6. Гудзий Н. Максим Грек и его отношение к эпохе итальянского Возрождения // Университетские известия. - Киев, 1911. - № 7.

7. Дунаев Б. Преподобный Максим Грек и греческая идея на Руси в XVI веке. - М., 1916.
Ильин М. Русское шатровое зодчест
ки середины XVI века. - М., 1980.

Лашкарёв П. Киворий как отличительная принад-

Масть алтаря в древней церкви. - Киев, 1883.

и его послания. - Киев, 1901: Гольнастыря Филофей сква - Третий Рим» в цикле сочинен Ай Идея «Моловины XVI века // ТОДРЛ. - Т. 37. - Л., 1983.

11. Подъяпольский С. Архитектор Петрок Малый // Памятники русской архитектуры и монументального искусства. - М., 1983

12. ПокровскийН. Иерусалим или Сион Софийской ри-

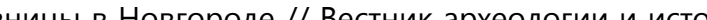
рии. - Вып. XXI. - СПб, 1911.

13. Роговин Н. Церковь Некрасов А.? Проблема про. - Вып. 5. - М., 1930.

Мсторическая библиотека - Т. 6, ч. 1 -СПб., 1908.
15. Словарь книжников и книжности Древней Руси. Вторая половина XIV-XVI век. - Ч. І. - Л., 1988.

6. Султанов Н. Русские шатровые церкви и их соотношение с грузинско-армянскими пирамидальными покрытиями // Труды V Археологического съезда в Тифлисе. - М., 1887.

17. Haney J. From Italy to Moscovy: The Life and Works of Maxim the Greek. Munchen, 1973.

18. Kivima Jeter Frjazin or Peter Hannibal An Italian Architect in Late Medieval:

19. Russia and Livonia // Settentrione. Rivista di studi italofinlandeesi. Anno V. Turku, 1983.

20. Miller D. The Lubeckers Bartholomaus Ghotan and Nicolas Bulow in Novgorod and Moscow and the Problem of Early Western Influences on Rusian Culture. - Viator, 1978, n. 9.

21. Wittkower R. Architectural Principles of the Age of Humanism. - London, 1973. 